\title{
Exploring University Instructors' Challenges in Online Teaching and Design Opportunities during the COVID-19 Pandemic: A Systematic Review
}

\author{
Sungmin $\mathrm{Na}$ \\ University of Washington, Seattle, USA \\ https://orcid.org/0000-0001-5370-4093 \\ Hyunggu Jung* \\ University of Seoul, Seoul, Republic of Korea \\ https://orcid.org/0000-0002-2967-4370
}

\begin{abstract}
As the pandemic began, university instructors shifted their classes online to ensure learning for numerous students. While teaching online, the instructors soon encountered many challenges. Existing studies have explored different kinds of challenges through surveys or interviews with instructors. However, to our knowledge, no studies have reported instructors' challenges in online teaching during COVID-19 through a systematic literature review. Moreover, there are no studies that have suggested design guidelines for creating tools to help instructors. Thus, we identified various challenges that university instructors face while teaching classes online, along with the causes of the challenges, through conducting a systematic review using the preferred reporting items for systematic review and meta-analysis (PRISMA) guidelines. Only the studies (a) reporting the challenges of instructors in online teaching, (b) having reported challenges regarding online teaching during COVID-19, and (c) reporting challenges of instructors from universities/colleges were considered in the systematic review. We found that the biggest category of the challenges that university instructors faced was managing/conducting online classes. Lastly, we propose design opportunities to help instructors to teach an online class more effectively and in interactive ways. This review shows the possibility of overcoming the existing challenges in online teaching with instructors receiving the appropriate support and tools for online classes. Additionally, we suggest some recommendations for future research. We hope this review contributes to a deeper understanding of university instructors' struggle in online classes and suggests potential solutions for supporting instructors in online education.
\end{abstract}

Keywords: systematic review; challenges; design opportunities; instructors; COVID-19

\footnotetext{
*Corresponding author: Hyunggu Jung; Email: hjung@uos.ac.kr
} 


\section{Introduction}

The coronavirus pandemic has made innumerable changes in our society, and education is no exception, being one of the sectors hugely impacted by the pandemic, according to the United Nations (Putri et al., 2020). Due to highly transmissible coronavirus, the World Health Organization (WHO) strongly advised people to avoid crowded places and close-contact settings, and confined and enclosed spaces. Considering the classroom setting, with students and instructors in close contact, and being a confined space, schools were unsafe for everyone. As of March 12th, 2020, 46 countries in five different continents decided to close schools, and 36 of these countries ordered country-wide closures affecting 408,679,886 learners (UNESCO, 2020a). Moreover, as the virus continued to surge, 161 countries fully closed their schools by April 21st, affecting over 1.5 billion learners; this means the pandemic has interrupted learning for at least 9 out of 10 students worldwide (Force, 2020). Students had no choice but to adapt to this new normal and take their classes online. Unfortunately, some students cannot even attend online classes because, especially in developing counties with digital inequality, they do not have access to digital devices (Khlaif \& Salha, 2020). Following the closure of schools, the rapid change from classroom to online teaching heavily influenced not only the learners but also the instructors (Okebukola, 2020). Instructors received immediate tasks in regard to "implementing distance learning modalities" (United Nations, 2020), such as having courses on online platforms, as the schools started to close due to the pandemic. However, these implementations were often carried out with a lack of guidance, training, or resources. For instance, in sub-Saharan Africa, Force (2020) reported, "only $64 \%$ of primary and $50 \%$ of secondary teachers have received minimum training, and this frequently does not include basic ICT skills", which are critical for online teaching. Trust and Whalen (2021) surveyed educators around the world and shared that $12 \%$ of the respondents mentioned their exhaustion of finding and learning the right tech tools for their classes without training and onsite tech support. These current situations clearly show that instructors need additional support to teach online. Therefore, it is crucial to understand how instructors struggle to teach online during the pandemic and assist these frontline responders who ensure the learning for almost 1.5 billion students (UNESCO, 2020b).

After institutions decided to move classes online amid the virus fears, instructors had to change traditional teaching methods and adjust to new online teaching platforms to maintain the delivery of significant learning experiences (Sunasee, 2020). Despite their hard work, however, various studies suggest instructors are still facing obstacles when teaching in remote classrooms. Thus, it is necessary to identify those challenges and provide appropriate support to lighten the burdens (Putri et al., 2020).

The researchers have conducted a review study on literature that reported the challenges of multiple stakeholders in online education. Prior studies conducted literature reviews and reported the challenges of a variety of stakeholders, such as college students (Sailsman, 2020), instructors (Islam et al., 2015), and both noninstructors (e.g., students, administrators of the institutions) and instructors (Al- 
Samarraie, 2019; de Lima et al., 2018; Kebritchi et al., 2017; Rasheed et al., 2020), in online education before the COVID-19 pandemic occurred. Similarly, recent review studies showed the challenges faced by stakeholders, such as college students, instructors, and administrators from higher education (Aini et al., 2020; Mseleku, 2020), and students and instructors from both secondary and tertiary educations (Pokhrel \& Chhetri, 2021), in online education during the COVID-19 pandemic. Nevertheless, previous studies did not identify the causes of the reported challenges that instructors faced in such scenario. Also, no prior studies suggested design considerations for creating tools to support instructors by addressing their challenges.

In this paper, we aim to collect those reported struggles amidst the pandemic by answering the following research questions:

- RQ1: What is the overview of the studies included in the systematic review?

- RQ2: What are the challenges that university instructors face when teaching online during the COVID-19 pandemic?

- RQ3: What are the causes of the identified challenges from RQ 2 that university instructors face when teaching online during the COVID-19 pandemic?

- RQ4: What are some design opportunities that can address the identified challenges?

Then, to answer these research questions, we conducted a systematic review of recent literature to find the ones that studied university instructors' challenges in online teaching. Analyzing the included studies in the review, this paper's contributions are threefold: (1) we provide an understanding of the challenges involved in teaching online in universities during COVID-19; (2) we report the causes of the identified challenges; (3) we recommend a set of design opportunities for creating tools that have a potential to support university instructors' online teaching. To our knowledge, this is the first study that aims to answer those questions using a systematic literature review.

\section{Methods}

To explore the challenges of instructors in online classes during the COVID-19 pandemic, we found relevant literature by conducting a systematic review, following the preferred reporting items for systematic review and meta-analysis (PRISMA) guidelines (Moher et al., 2009). Figure 1 exhibits a flow diagram that reflects the systematic review strategy adhering to the PRISMA (2009) Guidelines (Alshutwi, 2020).

\subsection{Literature Search Process}

First, in May 2021, we queried five different databases: Scopus, ACM, IEEE, PubMed, and EBSCO. For each database, we used the search string ("teachers" OR "instructors" OR "lecturers" OR "professors" OR "educators") AND ("online teaching" OR "distance education" OR "virtual teaching" OR "online lectures" OR "online lecture") AND ("challenges" OR "barriers" OR "obstacles" OR "struggles" OR "difficulties"). The search query was applied for at least one of the 
following items: title, abstract, keywords, or all text fields. Next, we specified the date range from January 1st, 2020 to April 30th, 2021, hoping to include all the studies that reported the challenges of instructors in online teaching during the COVID-19 pandemic. Finally, the initial search found 881 articles matching the keywords and date range. We refined our search results by removing 26 duplicates. Furthermore, after title and abstracts screening, 821 studies that were either literature reviews or not focusing on instructors' challenges in online teaching were also excluded.

\subsection{Eligibility Criteria}

The inclusion and exclusion criteria were set to ensure that the 34 results obtained were a collection of relevant studies for the systematic review. The studies included in this systematic review were selected using the following inclusion criteria:

- Reported the challenges of instructors in online teaching

- Reported challenges regarding online teaching must be during COVID-19

- Articles must report challenges of instructors who are from universities/colleges only.

On the other hand, we excluded studies that (a) did not meet the inclusion criteria, (b) were non-English articles, and (c) not journal articles or conference journals.

\subsection{Data Collection and Synthesis}

Finally, considering the inclusion and exclusion criteria, eight articles were included in the systematic review. We closely read those articles and highlighted the reported challenges of university instructors and their causes. Next, those highlighted challenges and causes were recorded on Google spreadsheets. We only recorded the challenges and causes from the result sections. Then we categorized the challenges into seven different groups and the causes into nine groups. 


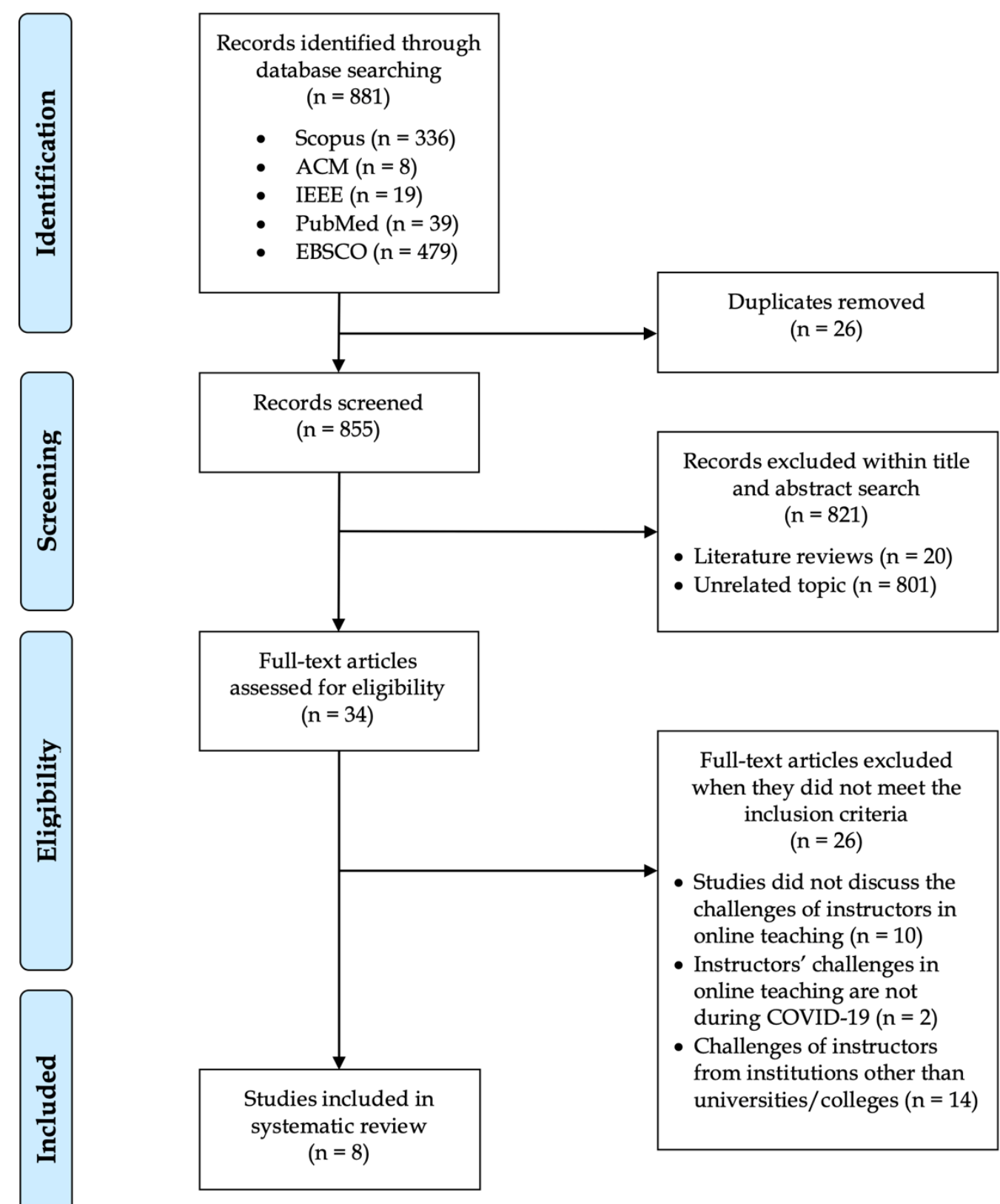

Figure 1: Systematic review strategy based on PRISMA (2009) Guidelines

\section{Results}

This section answers the research questions of this study by presenting the overview of the included studies in the review, reporting the challenges of university instructors in online teaching during the pandemic. Additionally, the following section explores the causes of instructors' challenges. 
Table 1: Overview of Included Studies in Systematic Review

\begin{tabular}{|l|l|l|l|l|}
\hline Article & $\begin{array}{l}\text { Country } \\
\text { of Study }\end{array}$ & Study Design & $\begin{array}{l}\text { Academic } \\
\text { Discipline(s) }\end{array}$ & $\begin{array}{l}\text { Sample } \\
\text { Size }\end{array}$ \\
\hline $\begin{array}{l}\text { Almazova et } \\
\text { al. (2020) }\end{array}$ & Russia & $\begin{array}{l}\text { Survey (quantitative); } \\
\text { Descriptive analysis }\end{array}$ & $\begin{array}{l}\text { Natural and applied } \\
\text { sciences }\end{array}$ & 87 \\
\hline $\begin{array}{l}\text { Bahar et al. } \\
\text { (2020) }\end{array}$ & Malaysia & $\begin{array}{l}\text { Interview (semi-structured); } \\
\text { Thematic analysis }\end{array}$ & $\begin{array}{l}\text { Natural and applied } \\
\text { science; Business }\end{array}$ & 8 \\
\hline $\begin{array}{l}\text { Gao and } \\
\text { Zhang (2020) }\end{array}$ & China & $\begin{array}{l}\text { Interview (semi-structured); } \\
\text { Thematic analysis }\end{array}$ & Humanities & 3 \\
\hline $\begin{array}{l}\text { Hadjeris } \\
\text { (2020) }\end{array}$ & Algeria & $\begin{array}{l}\text { Interview (structured); } \\
\text { Thematic analysis }\end{array}$ & $\begin{array}{l}\text { Humanities; Natural } \\
\text { and applied science }\end{array}$ & 7 \\
\hline Hazaea (2021) & $\begin{array}{l}\text { League } \\
\text { countries }\end{array}$ & $\begin{array}{l}\text { Survey (qualitative; posted } \\
\text { on open questions to } \\
\text { ResearchGate and Facebook); }\end{array}$ & $\begin{array}{l}\text { Humanities } \\
\text { Thematic analysis }\end{array}$ & 19 \\
\hline Huang (2020) & China & $\begin{array}{l}\text { Survey (quantitative); } \\
\text { Descriptive analysis }\end{array}$ & $\begin{array}{l}\text { Natural and applied } \\
\text { science }\end{array}$ & 56 \\
\hline $\begin{array}{l}\text { Joshi et al. } \\
\text { (2020) }\end{array}$ & India & $\begin{array}{l}\text { Interview (semi-structured } \\
\text { and in-depth); Thematic } \\
\text { analysis }\end{array}$ & $\begin{array}{l}\text { Did not report the } \\
\text { academic disciplines } \\
\text { of interviewees }\end{array}$ & 19 \\
\hline $\begin{array}{l}\text { Sunasee } \\
\text { (2020) }\end{array}$ & US & $\begin{array}{l}\text { Personal experience; } \\
\text { Narrative analysis }\end{array}$ & $\begin{array}{l}\text { Natural and applied } \\
\text { science }\end{array}$ & 1 \\
\hline
\end{tabular}

\subsection{Overview of Included Studies}

A total of eight articles were included in the review (see Table 1). The studies were conducted in different countries using varied research methods and included a diverse sample of university instructors. Two studies were conducted in China, and the rest in Malaysia, Arab League countries, India, Algeria, Russia, and the US. Though the studies were conducted in various countries, we found the most common setting for studies was Asia (62.5\%). The types of the study included four interviews (50\%), three surveys (37.5\%), and one personal experience $(12.5 \%)$. Five studies analyzed their collected data through thematic analysis $(62.5 \%)$, whereas two studies undertook a descriptive analysis $(25 \%)$, and the other one conducted narrative analysis (12.5\%). Overall, we found that interview is the most commonly used method for gathering data, and thematic analysis is the most common method used for analyzing collected data. Next, five studies included instructors who teach natural and applied sciences (e.g., chemistry, engineering, humanitarian sciences, information system, information technology, and logistics management) $(62.5 \%)$ while three studies included instructors who teach humanities (e.g., English) (37.5\%). Also, one study focused on instructors who teach business (e.g., accounting and finance, business administration, and marketing) (12.5\%), and the other study did not specify the academic discipline of the recruited instructors (12.5\%). Overall, we found that natural and applied sciences are the most common academic discipline among the included studies whereas business is the least common. Furthermore, four studies included less than 10 participants (50\%), two studies included $10-50$ participants $(25 \%)$, and the 
other two studies had 50-100 participants (25\%). However, the four studies including less than 10 participants did not report why this was the case.

Table 2: University instructors' challenges in online teaching during the pandemic

\begin{tabular}{|c|c|c|c|}
\hline Categories & Challenges & Causes & Articles \\
\hline \multirow[t]{7}{*}{$\begin{array}{l}\text { Challenges with } \\
\text { Managing/Conducting } \\
\text { Online Classes }\end{array}$} & $\begin{array}{l}\text { Difficult to conduct class } \\
\text { smoothly, without } \\
\text { interruptions }\end{array}$ & $\begin{array}{l}\text { Insufficient network } \\
\text { condition }\end{array}$ & \multirow[t]{2}{*}{$\begin{array}{l}\text { Gao and } \\
\text { Zhang (2020) }\end{array}$} \\
\hline & Difficult to manage class & $\begin{array}{l}\text { Students are not in the same } \\
\text { space as teachers }\end{array}$ & \\
\hline & Less control over the class & $\begin{array}{l}\text { Students' questions cannot } \\
\text { be answered in real time }\end{array}$ & Huang (2020) \\
\hline & $\begin{array}{l}\text { Continuity and efficiency get } \\
\text { interrupted during lecture } \\
\text { preparation and delivery }\end{array}$ & External distraction & \multirow[t]{4}{*}{$\begin{array}{l}\text { Joshi et al. } \\
(2020)\end{array}$} \\
\hline & Interrupt the flow of the class & Family interference & \\
\hline & $\begin{array}{l}\text { Confused about what process } \\
\text { to follow for online teaching }\end{array}$ & $\begin{array}{l}\text { Lack of clarity and direction } \\
\text { for online teaching }\end{array}$ & \\
\hline & $\begin{array}{l}\text { Difficult to conduct lectures } \\
\text { smoothly without any } \\
\text { disturbances }\end{array}$ & $\begin{array}{l}\text { Lack of technical } \\
\text { infrastructure }\end{array}$ & \\
\hline \multirow[t]{6}{*}{$\begin{array}{l}\text { Challenges with Using } \\
\text { Online Learning } \\
\text { Platforms/Software }\end{array}$} & $\begin{array}{l}\text { Being familiar with the chosen } \\
\text { education platform \& software }\end{array}$ & $\begin{array}{l}\text { Teachers have to become } \\
\text { familiar with online } \\
\text { education platforms in a } \\
\text { short time in response to } \\
\text { COVID-19 pandemic }\end{array}$ & Huang (2020) \\
\hline & $\begin{array}{l}\text { Difficult to adapt to Zoom since } \\
\text { they have no prior experience } \\
\text { with the app }\end{array}$ & $\begin{array}{l}\text { Rapid transition to online } \\
\text { remote teaching }\end{array}$ & $\begin{array}{l}\text { Sunasee } \\
(2020)\end{array}$ \\
\hline & $\begin{array}{l}\text { Have to use open-source online } \\
\text { teaching platforms, which lack } \\
\text { efficiency }\end{array}$ & $\begin{array}{l}\text { Not enough budget for } \\
\text { institutional-supported } \\
\text { technologies }\end{array}$ & \multirow[t]{4}{*}{$\begin{array}{l}\text { Joshi et al. } \\
(2020)\end{array}$} \\
\hline & $\begin{array}{l}\text { Difficult to use the online } \\
\text { platform for teaching }\end{array}$ & $\begin{array}{l}\text { Lack of training in online } \\
\text { teaching }\end{array}$ & \\
\hline & $\begin{array}{l}\text { Difficult to choose the right } \\
\text { online platform for delivering } \\
\text { lectures }\end{array}$ & $\begin{array}{l}\text { Various online teaching } \\
\text { platforms available }\end{array}$ & \\
\hline & $\begin{array}{l}\text { Feeling difficulty and being } \\
\text { tired about using online } \\
\text { platforms for teaching) }\end{array}$ & $\begin{array}{l}\text { Lack of online teaching } \\
\text { knowledge }\end{array}$ & \\
\hline \multirow[t]{3}{*}{$\begin{array}{l}\text { Challenges with } \\
\text { Teaching Class } \\
\text { Effectively }\end{array}$} & $\begin{array}{l}\text { Difficult to teach the class } \\
\text { effectively as instructors feel } \\
\text { uncertain about the platform, } \\
\text { channel, and specific skills, etc., } \\
\text { for online teaching }\end{array}$ & Lack of digital literacy & $\begin{array}{l}\text { Gao and } \\
\text { Zhang (2020) }\end{array}$ \\
\hline & $\begin{array}{l}\text { Lack of evident feedback on } \\
\text { teaching and learning }\end{array}$ & $\begin{array}{l}\text { Teachers cannot see } \\
\text { students when they are } \\
\text { delivering online instruction }\end{array}$ & Huang (2020) \\
\hline & $\begin{array}{l}\text { Difficult to deliver effective } \\
\text { online teaching in home } \\
\text { environment }\end{array}$ & $\begin{array}{l}\text { Lack of facilities, comfort } \\
\text { zone and resistance to }\end{array}$ & $\begin{array}{l}\text { Joshi et al. } \\
(2020)\end{array}$ \\
\hline
\end{tabular}




\begin{tabular}{|c|c|c|c|}
\hline & & $\begin{array}{l}\text { change at home } \\
\text { environment }\end{array}$ & \\
\hline & $\begin{array}{l}\text { Difficult to teach online } \\
\text { effectively }\end{array}$ & Lack of digital literacy & \multirow[t]{2}{*}{$\begin{array}{l}\text { Almazova et } \\
\text { al. }(2020)\end{array}$} \\
\hline & $\begin{array}{l}\text { Difficult to give collaborative } \\
\text { tasks for students despite the } \\
\text { course needs students to work } \\
\text { collaboratively }\end{array}$ & $\begin{array}{l}\text { Inability to use } \\
\text { active/collaborative } \\
\text { teaching methods using } \\
\text { certain platforms/software }\end{array}$ & \\
\hline \multirow[t]{4}{*}{$\begin{array}{l}\text { Challenges with } \\
\text { Interacting with } \\
\text { Students }\end{array}$} & $\begin{array}{l}\text { Difficult to have live discussion } \\
\text { online }\end{array}$ & $\begin{array}{l}\text { Commonly used platforms } \\
\text { such as "Moodle" and } \\
\text { "SANAKO" cannot reflect } \\
\text { the nature of the course } \\
\text { (students can only upload } \\
\text { course materials) }\end{array}$ & $\begin{array}{l}\text { Hadjeris } \\
(2020)\end{array}$ \\
\hline & $\begin{array}{l}\text { Ineffective real-time } \\
\text { communications }\end{array}$ & $\begin{array}{l}\text { Limited functions of school- } \\
\text { supported LMS }\end{array}$ & $\begin{array}{l}\text { Bahar et al. } \\
(2020)\end{array}$ \\
\hline & $\begin{array}{l}\text { Unable to communicate face-to- } \\
\text { face with students }\end{array}$ & Not reported & \multirow[t]{2}{*}{ Huang (2020) } \\
\hline & $\begin{array}{l}\text { Limited teacher-student } \\
\text { interaction }\end{array}$ & $\begin{array}{l}\text { Teachers cannot see } \\
\text { students when they are } \\
\text { delivering online instruction }\end{array}$ & \\
\hline \multirow[t]{4}{*}{$\begin{array}{l}\text { Challenges with Making } \\
\text { Students Participate and } \\
\text { Learn in Class }\end{array}$} & $\begin{array}{l}\text { Absence of students' } \\
\text { participation in online classes }\end{array}$ & $\begin{array}{l}\text { Students' lacking internet } \\
\text { connection at } \\
\text { home/insufficient network }\end{array}$ & \multirow[t]{2}{*}{$\begin{array}{l}\text { Hadjeris } \\
(2020)\end{array}$} \\
\hline & $\begin{array}{l}\text { Students' failure to learn } \\
\text { virtually }\end{array}$ & $\begin{array}{l}\text { Unavailability of } \\
\text { technological tools }\end{array}$ & \\
\hline & $\begin{array}{l}\text { Difficult to make students } \\
\text { participate in class and interact } \\
\text { with students }\end{array}$ & $\begin{array}{l}\text { Low rate of interactivity and } \\
\text { interaction }\end{array}$ & \multirow[t]{2}{*}{$\begin{array}{l}\text { Bahar et al. } \\
(2020)\end{array}$} \\
\hline & $\begin{array}{l}\text { Students' poor engagement and } \\
\text { decreased possibility of } \\
\text { achieving learner outcomes }\end{array}$ & $\begin{array}{l}\text { Lack of understanding of } \\
\text { learners' characteristics and } \\
\text { attitude }\end{array}$ & \\
\hline \multirow[t]{3}{*}{$\begin{array}{l}\text { Challenges with Course } \\
\text { Preparation }\end{array}$} & $\begin{array}{l}\text { Instructors struggled to prepare } \\
\text { their courses }\end{array}$ & Digital illiteracy & Hazaea (2021) \\
\hline & $\begin{array}{l}\text { Need to adjust teaching } \\
\text { methods }\end{array}$ & $\begin{array}{l}\text { Online education requires } \\
\text { instructors to change from } \\
\text { the old teaching paradigm } \\
\text { to a new teaching method } \\
\text { that matches the functions } \\
\text { of digitization }\end{array}$ & Huang (2020) \\
\hline & $\begin{array}{l}\text { Numerical, experimental and } \\
\text { communication subjects are } \\
\text { difficult to teach online }\end{array}$ & $\begin{array}{l}\text { Course integration with } \\
\text { technology }\end{array}$ & $\begin{array}{l}\text { Almazova et } \\
\text { al. (2020) }\end{array}$ \\
\hline \multirow[t]{2}{*}{$\begin{array}{l}\text { Challenges with Solving } \\
\text { Technical Issues }\end{array}$} & $\begin{array}{l}\text { Instructors facing technical } \\
\text { issues such as downloading } \\
\text { errors, installation failures, } \\
\text { slow internet connection, } \\
\text { storage capacity, and } \\
\text { compatibility issues with their } \\
\text { devices }\end{array}$ & Technology incompetence & $\begin{array}{l}\text { Bahar et al. } \\
(2020)\end{array}$ \\
\hline & $\begin{array}{l}\text { Having a hard time with } \\
\text { solving technical issues during } \\
\text { class since technical support is } \\
\text { not available at their home }\end{array}$ & Lack of technical support & $\begin{array}{l}\text { Joshi et al. } \\
(2020)\end{array}$ \\
\hline
\end{tabular}




\subsection{Challenges in Online Teaching during the COVID-19 Pandemic \& Causes of the Identified Challenges}

Overall, we identified seven different categories of challenges (see Table 2) and listed those categories in descending order of the number of challenges in each. The top two most frequently appeared categories of challenges are difficulty managing/conducting online classes and using online platforms/software. On the other hand, difficulty solving technical issues is the category with the least number of challenges. The cause of each challenge is also reported in Table 2.

\subsubsection{Challenges with Managing/Conducting Online Classes}

The first category of reported challenges of university instructors in online teaching is managing/conducting online classes. From Table 2, Gao and Zhang (2020) argued that instructors struggle to run online classes smoothly without disruptions due to insufficient network conditions. Other reported challenges point out that instructors and students not being in the same physical classroom can create challenges regarding managing online classes. One study mentioned that instructors feel challenged to manage their classes online since students and instructors are not in the same place (Gao \& Zhang, 2020). Another study also showed instructors feeling less control over their classes because they cannot answer students' questions in real time while being in different spaces (Huang 2020). Moreover, external distractions acted as barriers to successful online class management. Joshi et al. (2020) mentioned that instructors encounter external distractions such as noise created by neighbors, pets, vehicles, visitors, and family members in their homes. As a result, instructors often experience difficulties with delivering lectures without unwelcomed interruptions. The study also highlighted that unclear and insufficient directions from institutions made instructors feel more confused about what process to follow for online classes. Institutions without institutional-supported technologies or licensed platforms tend not to provide clear directions regarding conducting online classes, such as saying which online platform/software to use for online teaching. Lastly, Joshi et al. (2020) reported that lack of technical infrastructure (e.g., hardware, software, and internet) interrupts instructors from managing online classes. A great number of instructors struggle to run online classes smoothly as they are not equipped with laptops, microphones, cameras and have poor internet connections.

\subsubsection{Challenges with Using Online Learning Platforms/Software}

The second category is using online learning platforms/software. From Table 2, Huang (2020) reported that instructors had to become familiar with online education platforms quickly in response to the pandemic. Therefore, instructors struggled with adapting to their chosen education platforms and software. Sunasee (2020) also mentioned that the rapid transition to online teaching in response to COVID-19 had made instructors feel it more difficult to adapt to Zoom, a video conferencing software often used in online teaching, especially those having no prior experience with it. Joshi et al. (2020) revealed that some instructors do not feel confident about using online teaching platforms as they are not acquainted with such platforms.

Moreover, insufficient budget for institutional-supported technologies led to instructors' challenges with using online platforms for teaching (Joshi et al., 2020). 
Given lack of budget, institutions could not obtain licensed educational platforms/software, thereby directing instructors to use open sources. However, Joshi et al. (2020) reported that instructors believe open sources lack effectiveness compared to licensed sources due to the absence of useful features for online teaching. Moreover, institutions did not provide any training on open source platforms/software nor instruct instructors which one to use for delivering lectures, resulting in instructors struggling.

\subsubsection{Challenges with Teaching Online Classes Effectively}

From Table 2, some studies (Almazova et al., 2020; Gao \& Zhang, 2020; Huang, 2020; Joshi et al., 2020) reported instructors having challenges teaching online classes effectively. Gao and Zhang (2020) highlighted that instructors had to conduct online teaching with a lack of digital literacy due to a short training period. This meant that instructors quickly faced difficulty teaching their classes online as they felt uncertain about using platforms, channels, and other specific skills needed for online teaching. Similarly, Almazova et al. (2020) also revealed that lack of digital literacy made it difficult for instructors to teach online effectively since they were not ready to use various online applications, LMSs (Learning Management Systems), or web applications for their classes. Moreover, Huang (2020) reported that, because instructors cannot see their students while delivering online lectures, a lack of evident feedback on both teaching and learning is unavoidable. In the days of traditional face-to-face classes, instructors were able to teach the class more effectively based on noticeable feedback, including students nodding their heads, making puzzled faces, and raising their hands. Joshi et al. (2020) argued that some instructors believe online teaching is ineffective compared to conventional teaching methods. Because online teaching usually takes place in home environment settings, instructors often face issues such as lack of facilities, comfort zone, and resistance to change, which eventually lead to ineffective teaching. Lastly, Almazova et al. (2020) reported that instructors who teach courses that need students to work collaboratively struggle to teach their classes effectively since it is nearly impossible to organize pair work or small group discussions using certain platforms/software that are equivalent to face-toface communications.

\subsubsection{Challenges with Interacting with Students}

The next set of challenges involves with interacting with students during online classes. From Table 2, Hadjeris (2020) mentioned that commonly used online platforms such as Moodle or SANAKO allow students to upload their course materials only. Thus, instructors feel it is difficult to have live discussions with their students online as certain platforms do not support real-time interactions between instructors and students. Similarly, Bahar et al. (2020) pointed out instructors' ineffective real-time communication with students since schoolsupported LMS do not provide a function that allows instructors to have live interactions with their students. As a result, instructors have to use additional online software (for example, Zoom, Google Meet, Microsoft Teams, etc.) that support real-time interactions. Huang (2020) underscored that being unable to communicate face-to-face with students is one of the differences between online and in-person education and the greatest inconvenience experienced by instructors in online teaching. Huang (2020) also added that instructors have a 
difficult time interacting with their students, especially when they cannot even see the students' faces when sharing slides while delivering lectures.

\subsubsection{Challenges with Making Students Participate and Learn in Online Classes}

The fifth challenge category is getting students to participate and learn in online classes. From Table 2, Hadjeris (2020) reported that students' lack of internet connections and technological tools at their homes prevented students from participating and learning in online classes. Bahar et al. (2020) identified that instructors feel challenged in making students participate and learn as interactions with students are reduced in online classes. Additionally, an absence of proper understanding of students' characteristics and attitudes led to low engagement and decreased the possibility of achieving learner outcomes. For instructors, it is crucial to study the characteristics and attitudes of students so as to design and deliver learning experiences that fit with students' needs. However, Bahar et al. (2020) argued that it is not easy for instructors to learn about their students online and design courses that can fulfill their needs and encourage their full participation in online classes.

\subsubsection{Challenges with Online Course Preparation}

From Table 2, Almazova et al. (2020) Huang (2020), and Hazaea (2021) pointed out that instructors feel difficulty in preparing their online courses due to various circumstances. Digital illiteracy becomes a barrier once again for instructors who need to prepare virtual lessons using different technologies (Hazaea, 2021). In addition, online education requires instructors to adjust their previous teaching methods to fit in an online setting (Huang, 2020). This essential change would make it more difficult for instructors to prepare the online courses as it would take some time to accomplish. Lastly, not every course can be taught online. For example, instructors said that courses such as numerical, experimental, and communication subjects are difficult to be adjusted for online education since they require practices and queries that need to be handled face-to-face (Almazova et al., 2020).

\subsubsection{Challenges with Solving Technical Issues}

Lastly, from Table 2, Bahar et al. (2020) reported that instructors struggle with solving technical issues like downloading errors, installation failures, slow internet connection, storage capacity, and compatibility issues with their devices or hardware. For instructors who are not tech-savvy, they need tech support, which is unavailable from their homes. Similarly, Joshi et al. (2020) highlighted that instructors feel difficulty solving technical issues in online classes due to a lack of tech support. 
Table 3: Categorized causes of the identified university instructors' challenges in online teaching during the pandemic

\begin{tabular}{|c|c|c|}
\hline Categories & Causes & Articles \\
\hline \multirow{7}{*}{$\begin{array}{l}\text { Lack of Skills for Online } \\
\text { Teaching }\end{array}$} & Digital illiteracy & Hazaea (2021) \\
\hline & Technology incompetence & Bahar et al. (2020) \\
\hline & Lack of information technology literacy & Gao and Zhang (2020) \\
\hline & Lack of training in online teaching & \multirow[t]{3}{*}{ Joshi et al. (2020) } \\
\hline & $\begin{array}{l}\text { Various unfamiliar online teaching platforms } \\
\text { available }\end{array}$ & \\
\hline & Lack of online teaching knowledge & \\
\hline & Lack of digital literacy & Almazova et al. (2020) \\
\hline \multirow[t]{3}{*}{ Infrastructure Issues } & $\begin{array}{l}\text { Students' lacking internet connection at } \\
\text { home/insufficient network }\end{array}$ & Hadjeris (2020) \\
\hline & Insufficient network condition & Gao and Zhang (2020) \\
\hline & Lack of technical infrastructure & Joshi et al. (2020) \\
\hline \multirow[t]{3}{*}{$\begin{array}{l}\text { Need of Adjustment to } \\
\text { Teaching Methods for } \\
\text { Online Teaching }\end{array}$} & $\begin{array}{l}\text { Online education requires instructors to change } \\
\text { from the old teaching paradigm to a new } \\
\text { teaching method that matches the functions of } \\
\text { digitization }\end{array}$ & Huang (2020) \\
\hline & Course integration with technology & Joshi et al. (2020) \\
\hline & $\begin{array}{l}\text { Inability to use active/collaborative teaching } \\
\text { methods }\end{array}$ & Almazova et al. (2020) \\
\hline \multirow[t]{2}{*}{ External Distractions } & External distraction & \multirow[t]{2}{*}{ Joshi et al. (2020) } \\
\hline & Family interference & \\
\hline \multirow[t]{2}{*}{ Facility Issues } & Unavailability of technological tools & Hadjeris (2020) \\
\hline & Lack of basic facilities & Joshi et al. (2020) \\
\hline \multirow{2}{*}{$\begin{array}{l}\text { Instructors and Learners } \\
\text { Not Being in the Same } \\
\text { Place }\end{array}$} & Students are not in the same space as teachers & Gao and Zhang (2020) \\
\hline & $\begin{array}{l}\text { Teachers cannot see students when they are } \\
\text { delivering online instruction }\end{array}$ & Huang (2020) \\
\hline \multirow{2}{*}{$\begin{array}{l}\text { Lack of Support/Direction } \\
\text { for Online Teaching }\end{array}$} & Lack of technical support & \multirow[t]{2}{*}{ Joshi et al. (2020) } \\
\hline & Lack of clarity and direction for online teaching & \\
\hline \multirow[t]{2}{*}{$\begin{array}{l}\text { Rapid Transition to Online } \\
\text { Teaching }\end{array}$} & $\begin{array}{l}\text { Teachers have to be familiar with online } \\
\text { education platforms in a short time in response } \\
\text { to the COVID-19 pandemic }\end{array}$ & Huang (2020) \\
\hline & Rapid transition to online remote teaching & Sunasee (2020) \\
\hline \multirow[t]{2}{*}{ Software Issues } & $\begin{array}{l}\text { Commonly used platforms such as "Moodle" } \\
\text { and "SANAKO" cannot reflect the nature of the } \\
\text { course (students can only upload course } \\
\text { materials) }\end{array}$ & Hadjeris (2020) \\
\hline & Limited functions of school-supported LMS & Bahar et al. (2020) \\
\hline
\end{tabular}




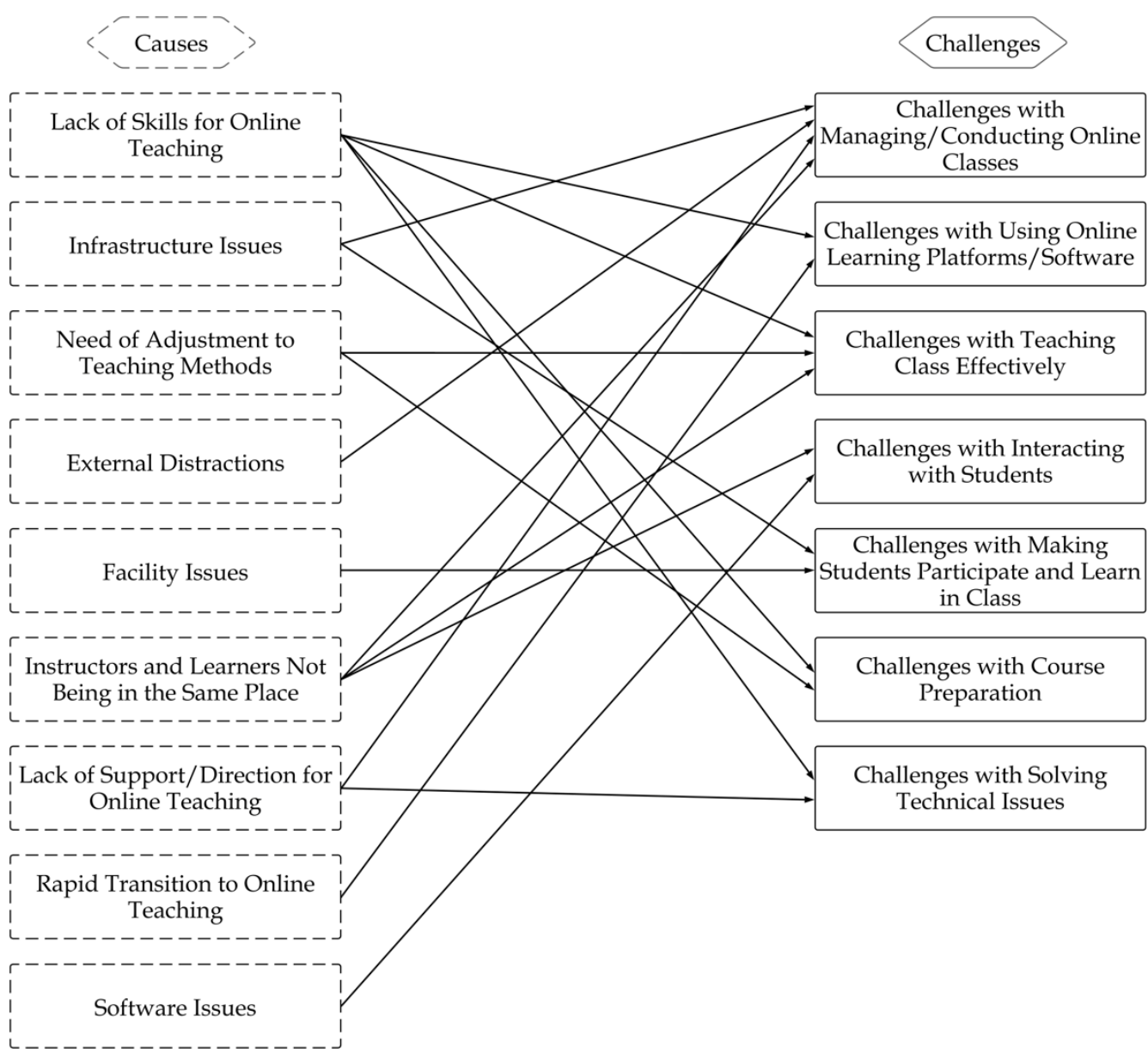

Figure 2: Arrow diagram of challenges of university instructors and their causes

\subsection{Causal Relationships}

The causes of the identified challenges were also grouped into separate categories, yielding nine different categories which were arranged in descending order of the number of causes included as shown in Table 3: (1) lack of skills for online teaching; (2) infrastructure issues; (3) need of adjustment to teaching methods for online teaching; (4) external distractions; (5) facility issues; (6) instructors and learners not being in the same place; (7) lack of support/direction for online teaching; (8) rapid transition to online teaching; and (9) software issues. Then, to clearly deliver an image of the causal relationship between the university instructors' challenges identified in Table 2 and their causes in Table 3, we draw an arrow diagram (see Figure 2). We put cause categories (dashed lines) on the left, in the order listed in Table 3, and challenge categories (solid lines) on the right, in the order listed in Table 2. Next, we connect each category of the causes to its corresponding challenge categories using arrows (see Figure 2). The arrow always starts from one cause and ends at the cause's corresponding challenge(s). For example, beginning from the first cause, "Lack of Skills for Online Teaching", the four arrows end at four challenges: using online learning platforms/software, teaching class effectively, course preparation, and solving technical issues. This part indicates that university instructors' lack of skills for online teaching has caused those four different challenges. 


\section{Discussion}

By investigating different literature through a systematic review, we attempted to understand various challenges of university instructors in online teaching during the COVID-19 pandemic. In this section, we reflect on our findings and discuss possible solutions for instructors' challenges. Then, we discuss the limitations of our study and future work.

\subsection{Instructors' Increased Workload in Online Classrooms}

We uncovered that one of the challenges that university instructors mainly struggle with is managing and conducting online classes. Several studies (Gao \& Zhang, 2020; Huang, 2020; Joshi et al., 2020) included in our systematic review highlighted that university instructors have difficulties regarding managing or conducting online classes due to various reasons, such as unstable network conditions, external distractions, and not being in the same physical space with learners. In line with that, other studies involving instructors in higher education underscored that instructors need to take care of their students' network conditions as they teach online (Kebritchi et al., 2017; Lao \& Gonzales, 2005). Unlike in traditional classes, online classes require instructors to have greater continual involvement in the management of online courses (Baran et al., 2013; Nambiar, 2020) as numerous uncontrollable factors like unstable networks or external distractions constantly hinder their teaching. Countries with severe weather conditions, such as heavy rainfall, lead to unavoidable connectivity issues and unavailability of technical support during online classes (Rusly et al., 2021). As a result, given the high expectation of instructors' increased involvement in online classes, they may feel overwhelmed about managing and conducting their classes. Therefore, it would be helpful if institutions could support university instructors to cope with this change and help lessen their burden promptly, considering the rapid increase in the number of online classes due to school closures during the pandemic.

\subsection{Instructors' Struggles of Adaptation to New Pedagogy}

Another challenge that university instructors struggle with is using online learning platforms and software in their online classes (Huang, 2020; Joshi et al., 2020; Sunasee, 2020). The newly emerged pedagogy amidst the pandemic has required the proficient use of online platforms or software for successful online teaching. However, Figure 2 reveals that instructors' lack of skills for online teaching has caused challenges with the use of online learning platforms and software. For some countries, online teaching might not be a major form of education. For example, teachers in Chinese schools had no previous experience in online teaching because it was infrequently used (Zhang et al., 2020). One of the studies included in our review also reported that online teaching is absent in Algerian teaching culture, and, accordingly, educators do not have sufficient knowledge regarding its application (Hadjeris, 2020). Instructors, especially in countries where online teaching is either absent or barely used, might not have sufficient experience and skills with using online platforms and software for teaching. Additionally, rapid transitioning to online teaching was another major cause of instructors' struggles with using online learning platforms and software. Online teaching usually requires instructors to invest a significant amount of 
time for setting up the online learning environment, uploading files, and creating new instructional materials (Baran et al., 2013; Samarawickrema \& Stacey, 2007). However, this could be a serious problem, especially in a time of pandemic. During the pandemic, instructors have been quickly shifted to online teaching from traditional teaching regardless of the levels of education (e.g., primary, secondary, tertiary, etc.) they belong due to rapidly deployed school closures. Even though the instructors had limited practical experience using online platforms for educational purposes, they had to proceed with online teaching and adapt to using those necessary platforms without sufficient time to practice them (Izhar et al., 2021). Huang (2020) also reported that university instructors had to be familiar with online education platforms in a short time in response to COVID19. Therefore, it would be crucial for institutions to provide university instructors workshops or programs preparing and training them for using online learning platforms and software.

\subsection{Instructors' Unfamiliarity with Technology}

We found that, out of all challenges, those involving solving technical issues are the least frequently appeared. Margaryan et al. (2011) argued that students of a technical discipline (e.g., engineering) used more technology tools when compared to students of a non-technical discipline (e.g., social work) since intensive and extensive access to technology was necessary for students taking engineering courses. Furthermore, along with the students of a technical discipline, the faculty of engineering also appeared to be more confident in their technology skills when compared with the faculty of social work (Margaryan et al., 2011). Therefore, it might be possible that challenges with solving technical issues were the least common challenges in our paper because the discipline of instructors from five out of eight studies in the review is natural and applied sciences, which is normally considered one of the technical disciplines. Additionally, we found multiple factors such as instructors' technology incompetence and unavailability of technical support lead to instructors struggling with solving technical issues in online classes. Another possible explanation for this struggle might be that instructors belonging to older generations and familiar with in-person teaching are likely to feel less comfortable using online technology for teaching. Akçayır (2016) reported that the current generation of digital natives, "the native speakers of the digital language" of computers and the internet (Prensky, 2001), are expected to encounter fewer problems while using technology because they grew up in an environment surrounded by technology.

On the other hand, the older generations, the digital immigrants, will be more likely to be unfamiliar with using technology and, therefore, face more technical issues in online teaching. Giacomini and Yamashiro (2008) also pointed out that, compared to university students, the digital natives, the instructors belonging to older generations, considered as digital immigrants, use technology less often. According to the survey conducted by Giacomini and Yamashiro, one and fivetenths times as many students bring their laptops to class as instructors, and four times as many students use instant messaging for educational purposes as instructors. Hence, university instructors who have difficulties solving technical 
issues during online classes might be teaching non-technical disciplines that usually demand less use of technology or belong to older generations who could be not familiar with utilizing technology for online classes. It might be helpful if institutions could focus on helping university instructors who are more likely to struggle with technical issues.

\subsection{Design Opportunities}

Based on the findings of our study, we delineate opportunities for creating support and designing tools for overcoming the challenges of university instructors and improving their experience in online teaching.

\subsubsection{Helping Instructors Gaining Online Teaching Knowledge}

We suggest institutions create tutorials that teach instructors how to use online learning platforms and software for their online courses. We found that having insufficient knowledge regarding online teaching could be a serious obstacle to teaching classes effectively, making students participate and learn in classes, and preparing online courses. Also, we discussed that instructors have had a lack of time to learn and practice online teaching due to the rapid transition to online in response to COVID-19. Therefore, providing instructors tutorials that would teach and guide them to conduct successful online classes would be useful. Moreover, having tutorials explaining the difference between various online platforms so instructors can choose the right one for their courses and sharing practical tips for managing online classes would be significantly helpful for instructors with a lack of online teaching knowledge. Furthermore, holding workshops about various online platforms and their features would help instructors get hands-on experience on different technologies, which would guide them in designing effective online courses.

\subsubsection{Creating a Feature that Provides Learner Feedback}

It is recommended that online learning platforms and software used in online classes include features that help instructors gain learners' feedback. We discovered that instructors have challenges with managing/conducting online classes and interacting with students due to the absence of learners' feedback. It is not difficult to receive learners' feedback (e.g., facial expressions, hand raising, etc.) in traditional classrooms since they are all in the same physical space. Unfortunately, it became harder to gain feedback from students regarding teaching because instructors and students were separated and unable to see each other. For instructors, learners' feedback is crucial because it allows them to quickly take the necessary actions for making their classes effective. Thus, we suggest developers create a feature that collects learners' feedback, such as facial expressions or motions (e.g., students nodding their heads, shaking their heads from side to side), interprets that feedback, and notifies instructors regarding learners' situations. This feature may allow instructors to check how their students are doing in class, respond accordingly without in-person interactions, and finally ensure managing and conducting online lectures successfully.

\subsubsection{Assisting Instructors with Technical Issues}

To help instructors with technical issues during online classes, we suggest developers consider adding a feature to online learning platforms or software that 
can give troubleshooting instructions to instructors in real time through online chat. A few studies (Bahar et al., 2020; Joshi et al., 2020) have highlighted instructors' need for technical support while preparing or conducting online classes. Normally, schools would have a separate tech support team helping instructors who face technical issues, but that help is not available as classes moved online due to COVID-19. Thus, by adding a chat feature to online platforms or software through which instructors can seek help right away when they encounter technical issues, we expect instructors to respond to those issues promptly and prepare/conduct online classes seamlessly. Furthermore, institutions having a separate tech support team that would assist instructors with tech issues during online classes through live chat or emails would be appreciated by the instructors.

\subsection{Limitations and Future Work}

This study has five limitations. First, we used five different electronic databases for this review. However, there could be other relevant literature available in other sources such as Google Scholar. Second, we excluded studies that were not written in or not available in the English language. Including relevant studies not written in English might have slightly changed our results. Third, we focused on challenges in online teaching from university instructors' perspectives only. Instructors who teach learners other than university students may have experienced different barriers in online teaching. Next, instructors in our sample lack diversity in terms of their countries and academic disciplines. Most of the instructors were from institutions located in Asia, and natural and applied sciences was the academic discipline of the majority of instructors. Examining the challenges of instructors from various countries and disciplines would have helped us gain a deeper insight and more generalizable findings regarding university instructors' challenges in online classes. Lastly, we purposefully included studies published between January 1st, 2020, and April 30th, 2021, to include studies reporting about university instructors' challenges during the COVID-19 pandemic specifically. However, since online education still continues in various countries and the pandemic is not over yet, there might be more studies concerning university instructors' challenges in online classes during the pandemic by the time we submit this review.

Future work remains to more thoroughly study the challenges encountered by instructors while teaching online. It would be significant to explore instructors from various countries and expertise as different contexts may create multiple challenges in online classrooms. Furthermore, it is essential to explore how the findings of our study may translate across different types of instructors, such as elementary school and high school teachers. In particular, to identify their challenges regarding online teaching in more detail, we would need to conduct surveys or interviews with instructors. Lastly, design opportunities proposed in this study can be applied to existing tools for online education or creating new tools and evaluating the effectiveness of the tool with a deployment study. 


\section{Conclusions}

In this study, our aim was to identify the challenges university instructors faced in online teaching during COVID-19, understand what caused the challenges we identified, and propose design opportunities that may help to address those challenges. The key contribution of this study is that the findings of this study provide a better understanding of how instructors are struggling and suggestions to support instructors for a better online teaching environment. We examined 881 studies published in online teaching during the pandemic from January 2020 to April 2021 through a systematic literature review. We then examined and categorized the reported challenges of university instructors in online teaching and their causes. Through this review, we identified seven different categories of challenges that university instructors are facing, along with nine categories of causes. More importantly, we learned that managing/conducting online classes and using online learning platforms/software are the top two categories of challenges of instructors among those seven different challenges. Additionally, based on those identified challenges, we proposed design opportunities that could guide in creating tools that can support instructors in online classes, contributing in deeper understanding of university instructors' struggle in online classes and suggesting potential solutions to assist the instructors. Thus, our study shows that university instructors may overcome the challenges in online classrooms if proper support is provided and appropriate tools designed for online teaching that can assist instructors effectively. Future work remains to utilize proposed design opportunities to create tools for supporting instructors in online education during the COVID-19 pandemic. Also, to confirm the feasibility and validity of the tools in online class settings, researchers may conduct a deployment study with multiple stakeholders involving instructors, students, and school administrators.

\section{Acknowledgements}

We appreciate HCAIL members for their constructive feedback on our initial manuscript. This work was supported by the National Research Foundation of Korea (NRF) grant funded by the Korea government (MSIT) (No. 2020R1G1A1009133).

\section{References}

Aini, Q., Budiarto, M., Putra, P. O. H., \& Rahardja, U. (2020). Exploring E-learning Challenges During the Global COVID-19 Pandemic: A Review. Jurnal Sistem Informasi, 16(2), 57-65. https://doi.org/10.21609/jsi.v16i2.1011

Akçayır, M., Dündar, H., \& Akçayır, G. (2016). What makes you a digital native? Is it enough to be born after 1980?. Computers in Human Behavior, 60, 435-440. https://doi.org/10.1016/j.chb.2016.02.089

Almazova, N., Krylova, E., Rubtsova, A., \& Odinokaya, M. (2020). Challenges and opportunities for Russian higher education amid COVID-19: Teachers' $\begin{array}{llll}\text { perspective. } & \text { Education } & \text { Sciences, } & \text { 10(12), }\end{array}$ https://doi.org/10.3390/educsci10120368

Al-Samarraie, H. (2019). A scoping review of videoconferencing systems in higher education: Learning paradigms, opportunities, and challenges. International Review of Research in Open and Distributed Learning, 20(3). http:/ /dx.doi.org/10.19173/irrodl.v20i4.4037 
Alshutwi, S. M., Ahmad, A. C., \& Lee, L. W. (2020). The Impact of Inclusion Setting on the Academic Performance, Social Interaction and Self-Esteem of Deaf and Hard of Hearing Students: Systematic Review and Meta-Analysis. International Journal of Learning, Teaching and Educational Research, 19(10). https://doi.org/10.26803/ijlter.19.10.14

Bahar, N., Wahab, S. N., \& Ahmad, N. D. (2020, December). Understanding Challenges Faced in Online Teaching and Learning Among Malaysian Universities' Instructors During COVID-19 Pandemic. In 2020 Sixth International Conference on e-Learning (econf) (pp. 154-157). IEEE.

Baran, E., Correia, A. P., \& Thompson, A. (2013). Tracing successful online teaching in higher education: Voices of exemplary online teachers. Teachers College Record, 115(3), 1-41.

de Lima, D. P. R., Gerosa, M. A., \& de Magalhães Netto, J. F. (2018, October). Using awareness information to enhance online discussion forums: a systematic mapping study. In 2018 IEEE Frontiers in Education Conference (FIE) (pp. 1-9). IEEE. https://doi.org/10.1109/fie.2018.8658487

Force, T. T. (2020). International Task Force on Teachers for Education 2030. https://teachertaskforce.org/knowledge-hub/covid-19-global-crisis-teachingand-learning

Gao, L. X., \& Zhang, L. J. (2020). Teacher learning in difficult times: Examining foreign language teachers' cognitions about online teaching to tide over COVID-19. Frontiers in Psychology, 11, 2396. https://doi.org/10.3389/fpsyg.2020.549653

Giacomini, C., \& Yamashiro, G. (2008). Assessing learning and scholarly technologies: Lessons from an institutional survey. Educause Quarterly, 31(3).

Hadjeris, F. (2021). Revisiting sustainable development Goal 4 in the context of COVID-19 Pandemic: A case study of online teaching in Algerian higher education institutions. Human Behavior and Emerging Technologies, 3(1), 160-168.

Hazaea, A. N., Bin-Hady, W. R. A., \& Toujani, M. M. (2021). Emergency remote English language teaching in the Arab league countries: Challenges and remedies. Computer-Assisted Language Learning Electronic Journal, 201-222. https://doi.org/10.1016/j.techsoc.2020.101317

Huang, J. (2020). Successes and Challenges: Online Teaching and Learning of Chemistry in Higher Education in China in the Time of COVID-19. Journal of Chemical Education, 97(9), 2810-2814. https://doi.org/10.1021/acs.jchemed.0c00671

Islam, N., Beer, M., \& Slack, F. (2015). E-learning challenges faced by academics in higher education. Journal of Education and Training Studies, 3(5), $102-$ 112. https://doi.org/10.11114/jets.v3i5.947

Izhar, N. A., Al-dheleai, Y. M., \& Na, K. S. (2021). Teaching in the Time of Covid-19: The Challenges Faced By Teachers in Initiating Online Class Sessions. https://doi.org/10.6007/ijarbss/v11-i2/9205

Joshi, A., Vinay, M., \& Bhaskar, P. (2020). Impact of coronavirus pandemic on the Indian education sector: perspectives of teachers on online teaching and assessments. Interactive Technology and Smart Education. doi:10.1108/ITSE-06-2020-0087

Kebritchi, M., Lipschuetz, A., \& Santiague, L. (2017). Issues and challenges for teaching successful online courses in higher education: A literature review. Journal of $\begin{array}{llll}\text { Educational Technology } & \text { Systems, } & \text { 46(1), }\end{array}$ https://doi.org/10.1177/0047239516661713

Khlaif, Z. N., \& Salha, S. (2020). The unanticipated educational challenges of developing countries in Covid-19 crisis: A brief report. Interdisciplinary Journal of Virtual Learning in Medical Sciences, 11(2), 130-134.

Lao, T., \& Gonzales, C. (2005). Understanding online learning through a qualitative description of professors and students' experiences. Journal of Technology and Teacher Education, 13(3), 459-474. 
Margaryan, A., Littlejohn, A., \& Vojt, G. (2011). Are digital natives a myth or reality? University students' use of digital technologies. Computers \& Education, 56(2), 429440. https:// doi.org/10.1016/j.compedu.2010.09.004

Moher, D., Liberati, A., Tetzlaff, J., Altman, D. G., \& Prisma Group. (2009). Preferred reporting items for systematic reviews and meta-analyses: the PRISMA statement. PLoS Medicine, 6(7), e1000097. https://doi.org/10.1371/journal.pmed.1000097

Mseleku, Z. (2020). A literature review of E-learning and E-teaching in the era of Covid19 pandemic. SAGE, 57(52), 588-597.

Nambiar, D. (2020). The impact of online learning during COVID-19: students' and teachers' perspective. The International Journal of Indian Psychology, 8(2), 783-793.

Okebukola, P. A., Suwadu, B., Oladejo, A., Nyandwi, R., Ademola, I., Okorie, H., \& Awaah, F. (2020). Delivering high school Chemistry during COVID-19 lockdown: Voices from Africa. Journal of Chemical Education, 97(9), 3285-3289. https:// doi.org/10.1021/acs.jchemed.0c00725

Pokhrel, S., \& Chhetri, R. (2021). A literature review on impact of COVID-19 pandemic on teaching and learning. Higher Education for the Future, 8(1), 133141. https://doi.org/10.1177/2347631120983481

Prensky, M. (2001). Digital natives, digital immigrants part 2: Do they really think differently? On the horizon, 9(6). https://doi.org/10.1108/10748120110424843

Putri, R. S., Purwanto, A., Pramono, R., Asbari, M., Wijayanti, L. M., \& Hyun, C. C. (2020). Impact of the COVID-19 pandemic on online home learning: An explorative study of primary schools in Indonesia. International Journal of Advanced Science and Technology, 29(5), 4809-4818. https:/ / doi.org/10.1108/JRIT-10-2018-0024

Rasheed, R. A., Kamsin, A., \& Abdullah, N. A. (2020). Challenges in the online component of blended learning: A systematic review. Computers $\mathcal{E}$ Education, 144, 103701. https://doi.org/10.1016/j.compedu.2019.103701

Rusly, N. H. M., Vijayaratnam, P., \& Sivarajah, A. (2021). COVID-19 Pandemic and Online Learning: The Challenges of Instructors in Tertiary Institutions. International Journal of Education and Pedagogy, 3(2), 14-26.

Sailsman, S. (2020). ESL Students Learning Online A Review of Literature. Quarterly Review of Distance Education, 21(1), 45-52.

Samarawickrema, G., \& Stacey, E. (2007). Adopting Web-Based Learning and Teaching: A case study in higher education. Distance education, 28(3), 313-333. https:// doi.org/10.1080/01587910701611344

Sunasee, R. (2020). Challenges of teaching organic chemistry during COVID-19 pandemic at a primarily undergraduate institution. Journal of Chemical Education, 97(9), 31763181. https:// doi.org/10.1021/acs.jchemed.0c00542

Trust, T., \& Whalen, J. (2021). Emergency remote teaching with technology during the COVID-19 pandemic: using the whole teacher lens to examine educator's experiences and insights. Educational Media International, 1-16. https:// doi.org/10.1080/09523987.2021.1930479

UNESCO, U. (2020a). COVID-19 educational disruption and response. UNESCO. https://en.unesco.org/themes/education-emergencies/coronavirus-schoolclosures

UNESCO, U. (2020b). COVID-19 impact on education. UNESCO Inst. Stat. data. https://en.unesco.org/covid19/educationresponse

United Nations. (2020). Policy brief: Education during COVID-19 and beyond. https://www.un.org/development/desa/dspd/wpcontent/uploads/sites/22/2020/08/sg_policy_brief_covid19_and_education_august_2020.pdf

Zhang, W., Wang, Y., Yang, L., \& Wang, C. (2020). Suspending classes without stopping learning: China's education emergency management policy in the COVID-19 outbreak. https://doi.org/10.3390/jrfm13030055 